\title{
Platybasia and Basilar Invagination
}

\author{
J.M.S. Pearce \\ Emeritus Consultant Neurologist, Department of Neurology, Hull Royal Infirmary and Hull York Medical School, \\ Hull, UK
}

\section{Key Words}

Basilar invagination • Basilar impression • Platybasia •

Chamberlain's line $\cdot$ Anders Retzius

\begin{abstract}
Descriptions of the flattening (platybasia) of the skull base and the upward displacement (impression) of the basilar and condylar portions of the occipital bone by the upper cervical spine date to the late 18th and early 19th centuries. Anatomical measurements to display these abnormalities were begun in 1865, but the full clinical significance was not appreciated until Homen's work in 1901. Subsequent refinement of radiology facilitated diagnosis and the later advent of surgical treatment.

Copyright $\odot 2007$ S. Karger AG, Basel
\end{abstract}

According to Spillane et al. [1] one of the first accounts of basilar invagination was that of Anders Adolph Retzius (1796-1860) and Frederik Theodor Berg (1806-1887) in 1855. It is found in the first section of Retzius's book [2] Impressio baseos cranii ex atrophia adiposa (cerea), part 4 (fig. 1). But earlier, in 1790, Ackermann is said to have described basilar invagination and a small posterior fossa in cretins from the Alps in 1790 [3].

Rokitansky first described the related occipitalisation of the atlas in 1844. Virchow [4] coined the term 'platybasia' to describe an abnormal flattening of the skull base, a defect which he attributed to abnormal bone development. However, in 1876 he reported the physical anthropology of the Germans with special consideration of the Frisians showing that basilar invagination was occa-

\section{KARGER}

Fax +41613061234 E-Mail karger@karger.ch www.karger.com
(C) 2007 S. Karger AG, Basel

0014-3022/07/0581-0062\$23.50/0

Accessible online at:

www.karger.com/ene

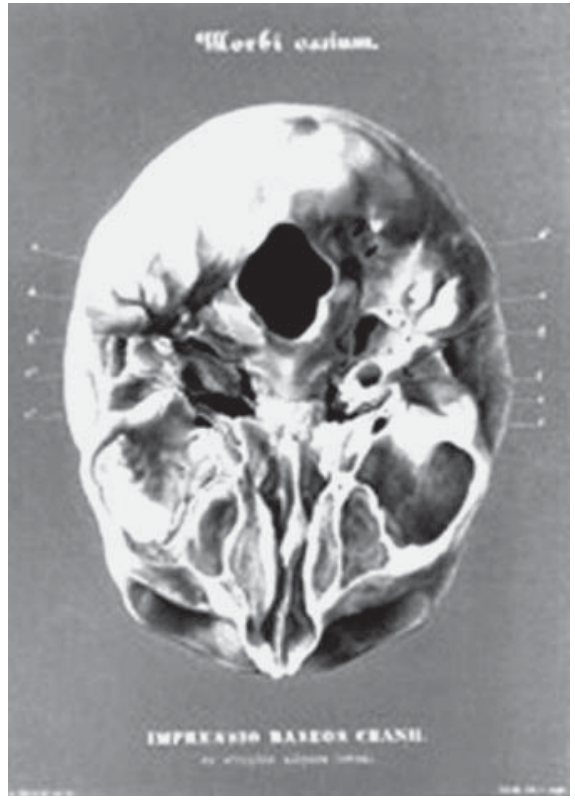

Fig. 1. Retzius and Berg: impressio baseos cranii.

sionally seen in association with platybasia [5]. In addition to flattening of the base of the skull, there was upward displacement (impression) of the basilar and condylar portions of the occipitalbone, which caused infolding, or impression of the foramen magnum, reduction of the posterior fossa, and consequent protrusion of the upper cervical spine into the anterior brainstem, with neurological signs. In 1865, Boogaard [6] extensively examined platybasia by using angular measurements in conjunction with his studies on basilar invagination. Over 50 
Table 1. Basilar invagination: some radiological signs

$\begin{array}{ll}\text { Chamberlain's line } & \begin{array}{l}\text { The tip of the dens is }>5 \mathrm{~mm} \text { above a } \\ \text { line joining the posterior edge of the } \\ \text { hard palate to the dorsal lip of the } \\ \text { foramen magnum } \\ \text { The tip of the dens is }>7 \mathrm{~mm} \text { above } \\ \text { the back of the hard palate to the } \\ \text { lowest point of the occipital squama } \\ \text { The intersection of the hard palate } \\ \text { and the plane of the atlas; } 13^{\circ} \text { is }\end{array} \\ \text { Bull's angle } & \begin{array}{l}\text { accepted as the upper limit of normal } \\ \text { Fischgold's digastric line joining the digastric grooves of } \\ \text { the mastoid processes on anteropos- } \\ \text { terior X-ray or transoral tomogram; } \\ \text { the } \\ \text { normally passes through the atlanto- } \\ \text { occipital articulation }\end{array}\end{array}$

years passed before Schuller [7], in 1911, established the radiological diagnosis, which was refined by Chamberlain [8] in 1939 and by other radiologists (table 1). However, no distinctive or detailed clinicopathological correlations were described.

\section{Basilar Impression or Invagination of the Skull}

Basilar invagination, the commonest malformation of the craniocervical junction [9], is a well recognised cause of neck pain, cough headache, lower cranial nerve palsies, corticospinal signs, hydrocephalus, cerebellar dysfunction, syringomyelia and syringobulbia, as first reported by Homen [10] in 1901. A short neck and flat skull base are often visible on inspection. Hypernasal speech, i.e. velopharyngeal insufficiency, with or without palatal clefts is an occasional clue. The neurological signs [11] are notably variable. It is associated with other malformations of the notochord and craniovertebral junction, such as occipitalisation of the atlas, Klippel-Feil anomaly, Chiari type I malformation and syringomyelia. The association of platybasia, occipitalisation of the atlas and fusion of cervical vertebrae in those with and without a Chiari malformation indicates a common developmental origin [12].

Occasional familial cases are recorded. One family in whom at least 6 individuals spanning 3 generations had primary basilar invagination is reported in which the 32year-old male proband had associated syringomyelia with neurological signs [13].

Secondary basilar invagination occurs in acquired bone diseases: Paget's disease, osteomalacia, osteogenesis imperfecta and localized bone destruction. Symptoms occur when the brainstem is compressed by the clivus or by the odontoid peg. About $80 \%$ of those with basilar impression have no associated Chiari malformation (group I); the remainder has both basilar impression and Chiari malformation (group II). The principal pathological characteristic is observed to be direct brainstem compression due to odontoid process indentation in group I and a reduction in posterior cranial fossa volume in group II. Altered CSF dynamics, pressure or traction on the brainstem and possibly impaired vertebrobasilar blood supply are possible mechanisms. When symptoms progress and threaten disability, treatment is by surgical decompression or by transoral odontoidectomy with reduction of the basilar impression and craniovertebral junction bony realignment, and atlanto-axial fixation $[14,15]$.

\section{Anders Retzius (1796-1860)}

Anders Retzius and his equally famed son Gustaf both worked at the Karolinska Institute and both were accomplished anthropologists. Anders enrolled at Lund University in 1812 and studied medicine at both Lund and Copenhagen, graduating MD in 1818 . He was appointed anatomist at the Karolinska Institute in 1824, becoming Professor of Anatomy in 1840. He executed many anatomical studies that enhanced contemporary descriptions of the teeth, skull, muscles and the nervous system. The retropubic space of Retzius is named after him. His anthropological work on the skull resulted in the classifications of skull types.

Following Robert Dunn's mid 19th century text on the morphology of the skull [16], Anders Retzius noticed that in Sweden the Germans had narrow skulls, while the skulls of the Lapps were broad; he clarified these shapes mathematically by his cephalic index of breadth/length. He described 4 types: orthognathous dolichocephalic, orthognathous brachycephalic, prognathous dolichocephalic and prognathous brachycephalic. Though still used descriptively, his classification did not confirm distinct racial patterns since the various forms appear within every race.

His brilliance was widely acclaimed and reflected by election to many academic societies. He fathered an equally celebrated son, Magnus Gustaf Retzius (18421919), physician and anatomist who studied the histology of the basilar membrane of the inner ear, sense organs and nervous system and after whom the Retzius cells in the leech (Hirudo medicinalis) were named. 


\section{References}

1 Spillane JD, Pallis CH, Jones AM: Developmental abnormalities in the region of the foramen magnum. Brain 1957;80:11-48.

2 Retzius A: Museum Anatomicum Holmiense Quod Auspiciis Augustissimi Regis Oscaris Primi Ediderunt Professores Regiae Scholae Medico-Chirurgicae Carolinensis. Sectio Pathologica. Holmiae, Ex Officina Norstedtiana, 1855.

3 Ackermann JF: Über die Kretinen, eine besondere Menschenabart in den Alpen. Gotha, Ettingersche Buchhandlung, 1790. Cited by Gonçalves da Silva JA, Marques de Almeida Holanda M: Basilar impression, Chiari malformation and syringomyelia: a retrospective study of 53 surgically treated patients. Arq Neuro-Psiquiatr (online), 2003, vol 61, No 2B. http://www.scielo.br/ pdf/anp/v61n2B/16249.pdf.

4 Virchow R: Untersuchungen über die Entwicklung des Schädelgrundes. Berlin, Reimer, 1856.

5 Virchow R: Beiträge zur physischen Anthropologie der Deutschen, mit besonderer Berücksichtigung der Friesen. Berlin, G. Vogt, 1876.
6 Boogard JA: De Indrukking der Grondvlakte van Schedel Dorr de Werwelkolom: Hare Oorzaken en Gevolgen (Basilar Impression: Its Causes and Consequences). Nederl Tysdschr v Geneesk. Tweede, Afedling, 1865, vol 1, pp 81-108. Cited by Koenigsberga RA, Vakila N, Honga TA, Htaik T, Faerber E, et al: Evaluation of platybasia with MR imaging. Am J Neuroradiol 2005;26:89-92.

7 Schuller A: Zur Roentgendiagnose der basilaren Impression des Schädels. Wien Med Wochenschr 1911;61:2594.

8 Chamberlain WE: Basilar impression (platybasia): a bizarre developmental anomaly of the occipital bone and upper cervical spine with striking and misleading neurologic manifestations. Yale J Biol Med 1939;11:487496.

9 Schmidt H, Sartor K, Heckl RW: Bone malformations of the craniocervical region; in Vinken PJ, Bruyn GW (eds): Handbook of Clinical Neurology. Amsterdam, North Holland Publishing, 1978, vol 32, pp 1-98.

10 Homen EA: Zur Kenntnis der rhachitischen Deformationen der Schädelbasis und der basalen Schädelhyperostosen. Dtsch Z Nervenheilkd 1901;20:1.
11 Ray BS: Platybasia with involvement of the central nervous system. Ann Surg 1942;116: 231-250.

12 Hayes M, Parker G, Ell J, Sillence D: Basilar impression complicating osteogenesis imperfecta type IV: the clinical and neuroradiological findings in four cases. J Neurol Neurosurg Psychiatry 1999;66:357-364.

13 Paradis RW, Sax DS: Familial basilar impression. Neurology 1972;22:554-560.

14 Bhangoo RS, Crockard HA: Transmaxillary anterior decompressions in patients with severe basilar impression. Clin Orthop Relat Res 1999;359:115-125.

15 Goel A: Progressive basilar invagination after transoral odontoidectomy: treatment by atlantoaxial facet distraction and craniovertebral realignment. Spine 2005;30:E551E555.

16 Dunn R: Some observations on the varying forms of the human cranium, considered in relation to the outward circumstances, social state, and intellectual condition of man. J Ethnol Soc Lond (1848-1856) 1856;4:33-54. 